IZA DP No. 8273

By Choice and by Necessity: Entrepreneurship and Self-Employment in the Developing World

David N. Margolis

June 2014 


\title{
By Choice and by Necessity: Entrepreneurship and Self-Employment in the Developing World
}

\author{
David N. Margolis \\ Paris School of Economics-CNRS \\ and IZA
}

Discussion Paper No. 8273

June 2014

IZA

P.O. Box 7240

53072 Bonn

Germany

Phone: +49-228-3894-0

Fax: +49-228-3894-180

E-mail: iza@iza.org

\begin{abstract}
Any opinions expressed here are those of the author(s) and not those of IZA. Research published in this series may include views on policy, but the institute itself takes no institutional policy positions. The IZA research network is committed to the IZA Guiding Principles of Research Integrity.

The Institute for the Study of Labor (IZA) in Bonn is a local and virtual international research center and a place of communication between science, politics and business. IZA is an independent nonprofit organization supported by Deutsche Post Foundation. The center is associated with the University of Bonn and offers a stimulating research environment through its international network, workshops and conferences, data service, project support, research visits and doctoral program. IZA engages in (i) original and internationally competitive research in all fields of labor economics, (ii) development of policy concepts, and (iii) dissemination of research results and concepts to the interested public.
\end{abstract}

IZA Discussion Papers often represent preliminary work and are circulated to encourage discussion. Citation of such a paper should account for its provisional character. A revised version may be available directly from the author. 
IZA Discussion Paper No. 8273

June 2014

\section{ABSTRACT \\ By Choice and by Necessity: Entrepreneurship and Self-Employment in the Developing World}

Over half of all workers in the developing world are self-employed. Although some selfemployment is chosen by entrepreneurs with well-defined projects and ambitions, roughly two thirds results from individuals having no better alternatives. The importance of selfemployment in the overall distribution of jobs is determined by many factors, including social protection systems, labor market frictions, the business environment, and labor market institutions. However, self-employment in the developing world tends to be low productivity employment, and as countries move up the development path, the availability of wage employment grows and the mix of jobs changes.

JEL Classification: J21, L26, O14, O17

Keywords: self-employment, entrepreneurship, development

Corresponding author:

David N. Margolis

Paris School of Economics

Centre d'économie de la Sorbonne

106-12 boulevard de l'Hôpital

75647 Paris cedex 13

France

E-mail : David.N.Margolis@gmail.com 
In the developing world, wage employment is often the exception rather than the norm. ${ }^{1}$ In the least developed countries, agriculture, often based in family farms with unpaid labor, can make up the majority of employment. As households migrate to urban areas and countries develop, nonagricultural self-employment often picks up where agricultural employment left off. Only as countries move up the development scale does wage employment become a large share of total employment. Accordingly, the World Bank's 2013 World Development Report, which focused on jobs, paid a significant amount of attention to the question of self-employment and entrepreneurship in the developing world.

The ubiquity of self-employment in low- and middle-income countries raises several important questions that this paper seeks to answer. First, how much self-employment is there in the developing world? Second, is self-employment in these countries a choice or a constraint? Third, to what extent does self-employment in the developing world correspond to the idea of "entrepreneurship"? And finally, from a normative perspective, is so much self-employment a good thing for developing countries? This paper addresses each of these questions by summarizing the wide academic literature on self-employment and development and presents additional evidence to provide a more complete picture where empirical evidence is more limited. The approach adopted here allies theoretical arguments (in particular, with respect to the "choice or constraint" question) with empirical results so as to provide a more complete vision of each issue.

The structure of this paper follows the four questions above. Section 1 takes a detailed look at the data to describe the prevalence of self-employment, and characterizes the self-employed population relative to those in wage employment. Section 2 returns to the question of constrained versus chosen self-employment, while section 3 considers the sub-population of "entrepreneurs" among the self-employed. Section 4 addresses the normative question of whether there is "too much" selfemployment in the developing world, while section 5 concludes.

\section{How much self-employment is there in the developing world?}

Although it may seem straightforward, quantifying the importance of self-employment in the developing world requires making several decisions that can directly affect the estimates. ${ }^{2}$ These include how one treats agriculture and household enterprises, notably the role of unpaid labor; the data source used to measure self-employment (individual, enterprise or expert surveys); the type of survey used (labor force survey, living standards measurement survey, census, specialized survey); efforts at harmonizing definitions and the use of imputation in the reporting of measurements.

\subsection{The role of agriculture and household enterprises}

The 2013 World Development report highlights the importance of agriculture in the least developed countries and the literature on the importance of non-agricultural household enterprises ${ }^{3}$ has insisted on their role as employment drivers in developing economies. In the cases of family farms and non-agricultural household enterprises, many family members can work for the same family-

\footnotetext{
${ }^{1}$ See Gindling and Newhouse(2012).

${ }^{2}$ See Desai (2009) for a discussion of some of these issues.

${ }^{3}$ See for example, Cho, Margolis and Robalino (2012), Chuhan-Pole et al (2011), Fields (2012).
} 
owned activity without a standard employer-employee relation and without a clear decisional hierarchy. In accordance with ILO recommendations ${ }^{4}$, statistical agencies will often code households in these situations as having a single own-account worker and multiple "contributing family workers" or "unpaid workers". However, the definition of a "contributing family worker" makes explicit reference to the self-employed nature of the person ${ }^{5}$, implying the need to include these individuals in any count of the self employed to ensure consistency.

Including contributing household workers makes a big difference in the calculation of the number of self-employed. Using the ILO's LABORSTA data for each country's most recently available data year and for middle- and low-income countries that report own-account and contributing family worker data, Table 1 shows how including contributing family workers can change the estimate of the importance of self-employment. On average, contributing family workers comprise over 25 percent of all self-employed. The share is larger for women than for men, as statistical agencies may have instructions to code the male in the household as the own account worker by default, in which case the spouse (and potentially children) would be coded as contributing family workers. Moreover, as noted above, contributing family workers are much more present in the agricultural sector than elsewhere, in that over one third of all self employed are contributing family members, and over half of women are in this situation. Although it is less the case for men, the importance of female contributing family labor is also remarkable in the fishing sector, where (as in agriculture), there are more women classified as contributing family workers than as own-account workers. In sum, ignoring the importance of (unpaid) contributing family workers on family farms and non-agricultural household enterprises can lead to a significant underestimation of the importance of selfemployment in the developing world.

Table 1: Share of employment by status

\begin{tabular}{|c|c|c|c|c|c|c|c|c|c|}
\hline & \multicolumn{3}{|c|}{ All sectors } & \multicolumn{3}{|c|}{ Agriculture, hunting and forestry } & \multicolumn{3}{|c|}{ Fishing } \\
\hline & Both Sexes & Men & Women & Both Sexes & Men & Women & Both Sexes & Men & Women \\
\hline Paid employees & $54.9 \%$ & $55.6 \%$ & $53.1 \%$ & $26.8 \%$ & $27.6 \%$ & $19.8 \%$ & $32.8 \%$ & $32.5 \%$ & $29.6 \%$ \\
\hline Self Employed & $41.9 \%$ & $41.3 \%$ & $43.5 \%$ & $69.0 \%$ & $68.6 \%$ & $74.3 \%$ & $67.1 \%$ & $67.3 \%$ & $70.2 \%$ \\
\hline Employers & $6.5 \%$ & $7.5 \%$ & $5.0 \%$ & $7.4 \%$ & $9.7 \%$ & $4.3 \%$ & $7.5 \%$ & $7.4 \%$ & $5.7 \%$ \\
\hline Own account & $24.7 \%$ & $25.9 \%$ & $21.7 \%$ & $36.7 \%$ & $41.6 \%$ & $27.7 \%$ & $44.5 \%$ & $47.1 \%$ & $27.5 \%$ \\
\hline Contributing Family & $10.7 \%$ & $7.8 \%$ & $16.8 \%$ & $25.0 \%$ & $17.3 \%$ & $42.3 \%$ & $15.1 \%$ & $12.8 \%$ & $37.0 \%$ \\
\hline
\end{tabular}

Source: ILO-Laborsta and author's calculations.

\subsection{Individual, enterprise or expert surveys?}

The source of information on the amount of self-employment in developing countries can also have an important impact on estimates of its level. Most estimates are either drawn from individual data (Labor force surveys (LFS), Living standards measurement surveys (LSMS), Censuses, Global Entrepreneurship Monitor (GEM) individual data, specialized surveys, etc.), enterprise data (Investment climate surveys (ICA), Business environment and enterprise performance surveys (BEEPS), informal sector surveys) or responses of experts to questionnaires (Doing Business data, GEM expert data). Each of these sources has advantages and disadvantages.

\footnotetext{
${ }^{4}$ http://www.ilo.org/global/statistics-and-databases/statistics-overview-and-topics/status-in-employment/ current-guidelines/lang--en/index.htm.

${ }^{5}$ Contributing family workers are defined as people “...who hold self-employment jobs in an establishment operated by a related person, with a too limited degree of involvement in its operation to be considered a partner".
} 
With the exception of specialized surveys such as the GEM Adult Population Survey ${ }^{6}$ or Grimm, Knorringa and Lay's (2012) West African informal sector data, individual-level data is rarely collected with the explicit purpose of measuring entrepreneurship. As mentioned above, the coding of employment status can lead to underestimation of self-employment, and in some cases data about income from self-employment are not collected due to questionnaire flow, as earnings questions in LFS data, for example, are typically only asked of "employees". The lack of focus on entrepreneurship also does not allow the user to easily distinguish the motivation of self-employment, nor the productivity, employment generation or growth potential of the enterprise. Individual data do, however, often have the advantage of being relative large samples that are representative of the potentially self-employed population (or can be rendered representative by weighting).

Enterprise survey data can also be used to measure self-employment and entrepreneurship, but its advantages (detailed information on the enterprise in question and, in some cases, sufficient information to assess growth potential) tend to be limited relative to the drawbacks associated with using this data for the measurement and analysis of self-employment and entrepreneurship. First, in most cases, a minimum-size threshold is imposed on the sampling scheme ${ }^{7}$, excluding de facto the majority of self-employment enterprises in the developing world ${ }^{8}$. Second, these data often rely on firm registries to establish their sample frames, thereby ignoring the informal sector which is host to many self-employed enterprises. Lastly, several informal sector surveys adopt a "block enumeration" sampling strategy ${ }^{9}$, which generates non-representative samples of limited (usually urban) geographic areas.

The main expert surveys that are relevant for studying self-employment and entrepreneurship are the World Bank's Doing Business ${ }^{10}$ surveys and the Global Entrepreneurship Monitor's National Expert Surveys ${ }^{11}$. The role of these surveys is primarily to characterize the environment in which the self-employed operate and take their decisions. As such, they are not directly useful for measuring the amount of self-employment or entrepreneurship, but they can be valuable resources for understanding cross-country differences in self-employment rates.

\subsection{LFS? LSMS? Census? Specialized surveys?}

As noted above, there are several types of individual data that can be used to quantify selfemployment, in particular LFS, LSMS, Censuses and specialized surveys. As with other data sources, each has its advantages and disadvantages, with the differences between sources corresponding broadly to a tradeoff between sample size/representativity and level of detailed information about self-employment and entrepreneurial activity. The censuses have, obviously, the broadest coverage and are the most representative data source, but not all censuses will code labor market status while available demographic and income information is usually very limited. Labor force surveys will often

\footnotetext{
${ }^{6}$ See Bergmann, Mueller and Schrettle (2013) for a specific discussion of the advantages and disadvantages of the GEM data for academic research. Relative to other individual databases, some of its primary disadvantages relate to sample size, sampling strategies and transferability of the developed-country questionnaire to the developing-country context.

${ }^{7}$ See http://www.enterprisesurveys.org/Methodology, for example.

${ }^{8}$ See Tybout (2000). More recently, Sandefur (2010) shows that 85 percent of manufacturing firms in Ghana in 2003 had fewer than 10 employees per establishment

${ }^{9}$ See http://www.enterprisesurveys.org/Methodology for details.

${ }^{10}$ See http://doingbusiness.org/.

${ }^{11}$ See http://www.gemconsortium.org/.
} 
be of relatively large size and include a standard set of demographic characteristics and labor market status, but generally lack more detailed information on outcomes from self-employment and growth potential. Living standards measurement surveys (and similar instruments such as household income or expenditure surveys) will typically have smaller sample sizes than an LFS, and may have more restrictive geographic coverage. They will, however, often include income from self-employment and available household assets, and may include a more thorough characterization of the selfemployment activity. However, as the focus is not on entrepreneurship per se, evaluation of the growth potential of the entrepreneurial activity can require additional hypotheses or modeling. Lastly, specialized surveys have the distinct advantage of asking precisely the questions that are needed to assess productivity and entrepreneurial growth potential. However, as they tend to be narrowly focused and intensive questionnaires, the sample sizes are often small and representativity may be an issue.

A common risk to using most sources of individual data is measurement error due to proxy response. This occurs when the survey questions refer to a person different from the one who actually responds to the survey (the proxy). Although it seems unlikely that proxy response will significantly affect estimates of the number of self-employed ${ }^{12}$, these data may be less reliable for measuring determinants of productivity or reasons for self-employment.

\subsection{Harmonized definitions and imputation}

An obvious concern with estimating the prevalence of self-employment in the developing world is ensuring that common definitions are used in all contributing countries. International repositories such as the ILO's ILOSTAT and KILM databases, or the World Bank's International Income Distribution Database (I2D2) archive devote significant resources to ensuring comparability across countries in variable definitions, but not all differences are correctable and extra information may be needed. The ILO has promulgated a standard for defining labor market status, called the International Classification by Status in Employment (ICSE) ${ }^{13}$, but not all countries adopt it and it has been revised (slightly) over time. In the ILO's LABORSTA database (currently being phased out in favor of the ILOSTAT database), labor market status in tables $1 \mathrm{C}$ and 1D was coded according to 2 different nomenclatures under the same variable name, and a second variable was needed to identify the information to which the variable refers. For example, if the country used ICSE-1993, one variable measures the number of employees, whereas if the country used ICSE-58, the same variable refers to Employers and own-account workers. Not accounting for differences in the nomenclature used in each country can thus generate highly misleading estimates of self-employment rates.

A more subtle problem resides in the imputation of missing labor market data. Developing countries often do not produce labor market data on a regular basis ${ }^{14}$ (see Figure 1), although major international repositories (such as the ILO's Key Indicators of the Labor Market (KILM)) present figures for countries, even when the underlying data does not exist, by using imputation models. The assumptions and techniques used in these models can be debated ${ }^{15}$ and can have major impacts on estimated shares of self-employed, often by drawing particular country shares toward average rates

\footnotetext{
${ }^{12}$ Dillon et. al. (2012) show, for example, that proxy response does not generate significant errors in the much more sensitive case of child labor reports in Tanzania.

${ }^{13}$ See http://laborsta.ilo.org/applv8/data/icsee.html.

${ }^{14}$ See Margolis, Newhouse and Weber (2010a).

${ }^{15}$ See Weber and Denk (2011) for a detailed discussion of imputation techniques for labor market data.
} 
in the same sub-region for similar types of workers. This approach can have the effect of giving excessive importance to the (sometimes) few countries that actually collect data regularly, and tend to have more sophisticated statistical administrations. Perhaps unsurprisingly, these countries (especially in the Sub-Saharan African region) are among the most developed ${ }^{16}$, which could bias the imputations if the country missing the data is significantly poorer and there is a link between the share of self-employment and the level of development. Such a link has indeed been found in several studies $^{17}$, and suggests that one should be particularly attentive to imputation techniques if one absolutely needs annual data; otherwise, a safer approach is to restrict attention to years when actual data is available.

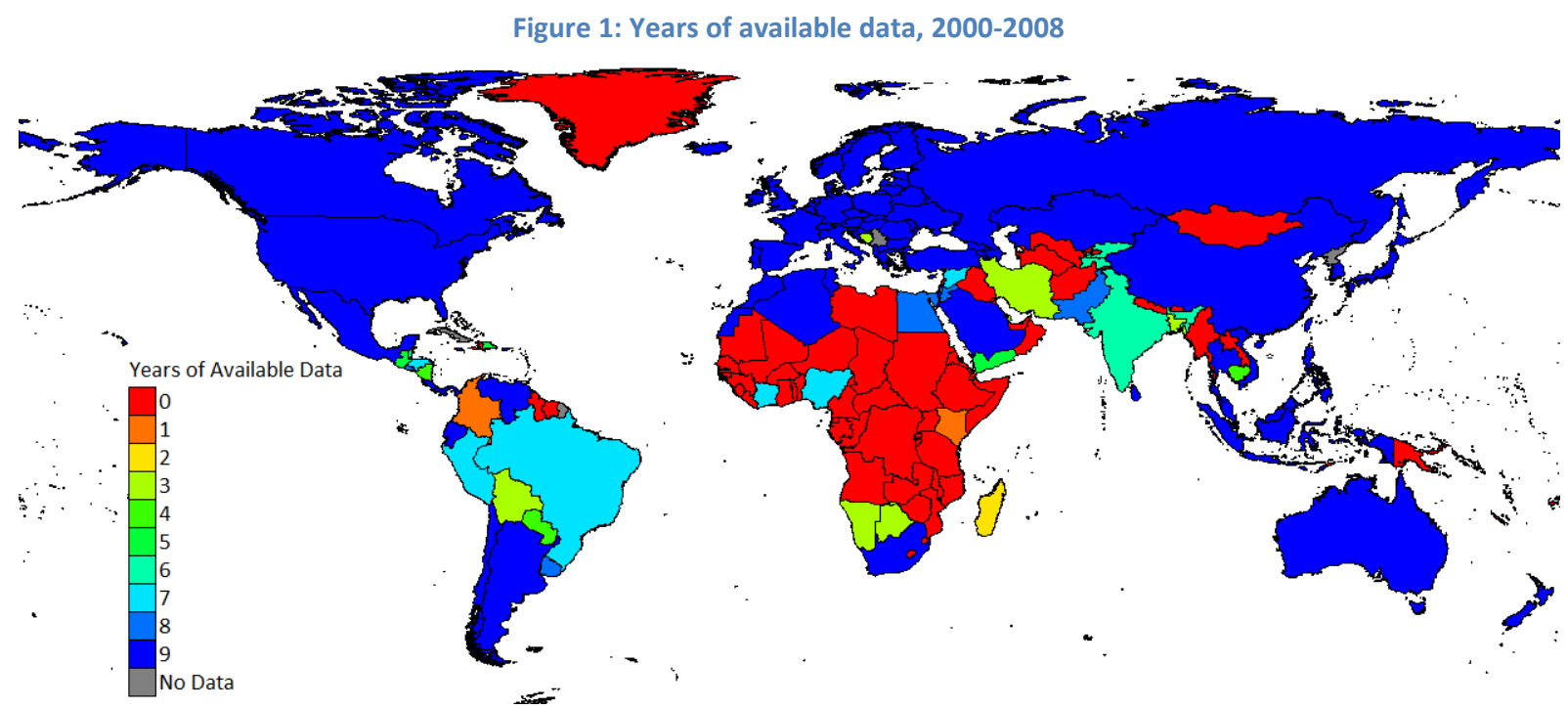

Source: Margolis, Newhouse and Weber (2010b).

\subsection{Several "Best guesses"}

Perhaps the most detailed presentation of self-employment in the developing world comes from Gindling and Newhouse (2012), who exploit the harmonized individual data on developing countries collected in the World Bank's 12D2 data archive. They find that among all low and middle income countries in their sample ${ }^{18}$ combined, the share of wage employment is 49.3 percent, whereas in high income countries (over $\$ 12,275$ in GDP per capita) the share of wage employment is 85.9 percent. 32.7 percent of workers in developing countries are "own account" self-employed, 15.4 percent are unpaid and 2.7 percent are employers, highlighting the importance of defining selfemployment precisely.

Gindling and Newhouse (2012) also break down self-employment along several dimensions. For example, non-agricultural self-employment plus agriculture accounts for the majority of male employment in all regions except Europe and Central Asia (28 percent) and the Middle East and

\footnotetext{
${ }^{16}$ Mauritius and South Africa were the only two countries in the SSA region that produced data for LABORSTA every year between 2000 and 2008.

${ }^{17}$ See, for example, Gindling and Newhouse (2012), Xavier et. al. (2013).

${ }^{18}$ It is important to note that the I2D2 sample used by Gindling and Newhouse (2012) covers an estimated 63 percent of the population of low and middle income countries, and 60 percent of all countries worldwide. The main loss of worldwide population comes from the lack of data on China (coverage of East Asia and Pacific developing countries is only 21\%) and some larger Middle East and North Africa countries, such as Algeria, Iran, Iraq and Lebanon (regional coverage among MENA developing countries is 46 percent).
} 
North Africa (46 percent), going as high as 82 percent of male employment in Sub-Saharan Africa (see Table 2). On the other hand, self-employment is higher than wage employment for working women in MENA, although wage employment is more important in the Latin America and Caribbean region. In South Asia, East Asia and the Pacific and Sub-Saharan Africa, self-employment outnumbers wage employment, especially for women.

Table 2: Self-Employment (and Agricultural Employment) Shares by Region and Sex

\begin{tabular}{|c|c|c|c|c|c|c|}
\hline & ECA & LAC & MENA & SA & EAP & SSA \\
\hline \multicolumn{7}{|c|}{ Working-Age Population (15-65) } \\
\hline Men & $18 \%$ & $34 \%$ & $33 \%$ & $55 \%$ & $51 \%$ & $59 \%$ \\
\hline Women & $9 \%$ & $17 \%$ & $21 \%$ & $23 \%$ & $34 \%$ & $55 \%$ \\
\hline \multicolumn{7}{|c|}{ All Employment } \\
\hline Men & $28 \%$ & $59 \%$ & $46 \%$ & $68 \%$ & $64 \%$ & $82 \%$ \\
\hline Women & $21 \%$ & $35 \%$ & $66 \%$ & $82 \%$ & $67 \%$ & $92 \%$ \\
\hline \multicolumn{7}{|c|}{ Non-Agricultural Employment } \\
\hline Men & $12 \%$ & $29 \%$ & $25 \%$ & $42 \%$ & $37 \%$ & $52 \%$ \\
\hline Women & $6 \%$ & $29 \%$ & $21 \%$ & $44 \%$ & $47 \%$ & $76 \%$ \\
\hline
\end{tabular}

Source: Gindling and Newhouse (2012) Figure 3, author's calculations.

The Global Entrepreneurship Monitor presents another perspective on the question of entrepreneurship and self-employment, through their measures of "Total Early-Stage Entrepreneurial Activity" (TEA) ${ }^{19}$ and established businesses ${ }^{20}$. Although the average estimates are unweighted and the country groupings differ somewhat from those of Gindling and Newhouse (2012), the results are qualitatively similar. TEA is highest in Sub-Saharan Africa and men outnumber women, with the smallest difference being in Sub-Saharan Africa.

\footnotetext{
${ }^{19}$ TEA is defined (Xavier et. al. (2013), p. 13) as the sum of nascent entrepreneurs (those starting new enterprises less than three months old) and new business owners (former nascent entrepreneurs who have been in business for more than three months, but less than three and a half years).

${ }^{20}$ Established businesses are those that have been in existence for more than three and a half years (Xavier et. al. (2013), p.13).
} 


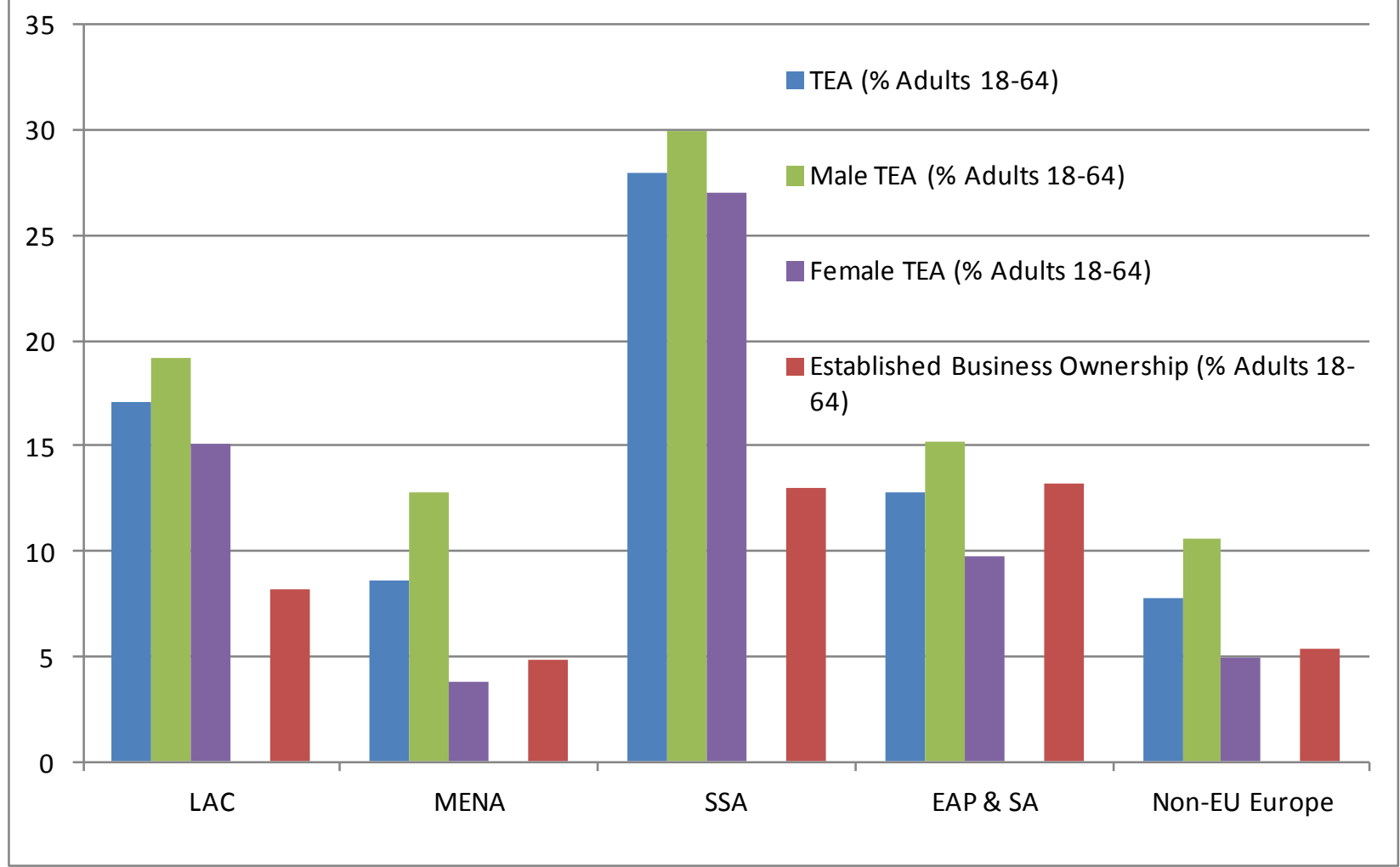

Source: Xavier et. al. (2013) appendix tables 2 and 3 and author's calculations.

There are important differences between the GEM and I2D2 measures of self-employment that can affect one's perception of self-employment and entrepreneurship in the developing world. In the GEM data, the focus is on entrepreneurial activity and contributing family labor is ignored, thereby excluding a large share of self-employed workers, particularly women. On the other hand, the I2D2 data presented here do not distinguish by the age of the enterprise and do not separate out agricultural wage employment from the rest of agricultural employment. Nevertheless, the sum of TEA and established business (plus 8 to 17 percent for contributing family workers) should generate figures comparable to the 12D2 numbers. Some of the quantitative differences between the data underlying Figure 2 and Table 2 are likely due to the way in which the data was collected ${ }^{21}$, the countries for which data is available in each study (the largest differences appear in MENA and EAP \& $\mathrm{SA}$ ) and whether or not the averages give larger countries more weight than smaller countries ${ }^{22}$.

\section{Self-employment: by choice, by necessity or both?}

Although much of the research on entrepreneurship in the developed world treats self-employment as a decision, this question is very much debated in the developing world context. ${ }^{23}$ In many

\footnotetext{
${ }^{21}$ Most surveys in the GEM data use telephone interviewing, which will tend to under-sample poor households who cannot afford telephones and may be more likely to be subsistence entrepreneurs.

${ }^{22}$ The Gindling and Newhouse (2012) results weight the averages by population (larger countries get more weight), while Xavier et.al. (2013) equally weight countries in their tables.

${ }^{23}$ See, for example, Fields (2012) or Poschke (2013a) for the "necessity" perspective and some of the work of David McKenzie and coauthors (such as de Mel, McKenzie and Woodruff (2008)) for the "opportunity" perspective. Perry et. al. (2007) presents both sides in a study for Latin America, while Bosch and Maloney (2011) present an empirical analysis of transitions into and out of self-employment.
} 
developing countries, formal safety nets do not exist and not working can mean starvation. As a result, ILO-definition unemployment (not working but looking for work and available to start a job) is often very low in developing countries where it can be calculated, as individuals in need who do not have access to subsistence agriculture will start their own microenterprises to earn at least the minimum necessary to survive.

Although the different types of self-employment go by various names (Opportunity or necessity? Exit or exclusion? Choice or constraint? De Soto or Tokman?), both will typically exist simultaneously in any given country. ${ }^{24} \mathrm{~A}$ variety of factors determine the share of self-employed in a country and how many are there by choice versus by constraint, from supply-side factors (that operate on the individual) to market and demand factors (that affect the opportunities an individual has available). ${ }^{25}$ What follows is a discussion of the main determinants of total self-employment and the share of necessity versus choice-driven self-employment in a given environment.

\subsection{Formal and informal social protection}

When workers have access to sources of income other than labor income, they can afford to search for the best available wage job ${ }^{26}$ or, if they prefer, choose self-employment. When workers lack access to alternative income sources, they must live off of savings, transfers and household production until they can find paying work. As savings diminish, reservation utility falls and any sort of work becomes preferable to the alternative which, in the limit, can be starvation. In these cases, an individual may be constrained to start his or her own business, even a very low productivity one, when funds run out. In developing countries, where many people are poor and have limited savings, circumstances can quickly turn dire, especially when a health or other shock occurs.

Social protection is designed to palliate this risk, by providing individuals with a "safety net" to allow them to survive, ideally until they can provide for themselves. Although formal safety nets in developing countries are often limited ${ }^{27}$, family solidarity can play a similar role, at least in the short term. However, countries with weaker social protection systems and cultures that are less oriented toward providing others in the family or community with support when needed are more likely to have a higher share of necessity, as opposed to choice-driven, self-employed.

\subsection{Labor market frictions}

Even when individuals have the resources necessary to support unemployed job search, they must still search. Nobody knows all of the job opportunities for which he or she is qualified that are potentially available at any point in time and can costlessly get to the jobs. Labor market frictions make information about where jobs are available and how much they pay costly to obtain (in time, energy and sometimes financial resources), while transportation costs and particularly low wages can make some jobs not worthwhile even when information is available. In developing countries where infrastructure can be deficient, information can circulate slowly, workers often lack appropriate skills and labor markets are full of frictions that provide employers with the power to suppress

\footnotetext{
${ }^{24}$ Schoar (2010) uses an alternative distinction between subsistence and transformational entrepreneurs, but her categories often resemble those found elsewhere in the literature. Papers such as de Mel et. al. (2010a) address this distinction directly.

${ }^{25}$ Poschke (2013b, 2013c) and Margolis and Robalino (2013) present decision-theoretic frameworks for modeling entry into self-employment, and subsequent success, in the developing world.

${ }^{26}$ See Meyer (1990), for example.

${ }^{27}$ See the World Bank's ASPIRE database for details (http://datatopics.worldbank.org/aspire/).
} 
competition and drive wages down (effective monopsony power), the perfectly competitive labor market model is inapplicable and it becomes necessary to search for sufficiently remunerated work. As in the case with social protection, countries with worse infrastructure and more information or labor market frictions will tend to have more individuals unable to find a wage job quickly, and thus a higher share of constrained self employed.

\subsection{Business environment}

In order to be able to choose between wage and self-employment, enough wage jobs have to exist (and have to be findable). The ability of employers to create wage jobs depends heavily on the business environment. Multiple data sources, typically based on surveys of national experts, exist to assess the institutional constraints and costs of doing business, as well as the ease of investment and employment growth ${ }^{28}$. There are also firm-based surveys ${ }^{29}$ in which current firms are asked to assess the importance of particular constraints to growth and job creation. While the expert surveys tend provide a broader view of the business environment and the various constraints existing and potential entrepreneurs might face, the enterprise surveys are more able to provide quantitative assessments of the importance of various constraints and subjective rankings from the perspective of the employer.

The business environment affects the share of workers in self-employment overall as well as the share of the self-employed who are there by choice versus necessity. In countries where potential entrepreneurs have only a limited access to capital, ${ }^{30}$ there will be fewer "choice" entrepreneurs (necessity entrepreneurs will still start their businesses, even if undercapitalized) and the share of the population in chosen self-employment will be lower. ${ }^{31}$ Moreover, existing firms may find it difficult to grow and hire additional workers, thereby reducing the availability of wage jobs and tilting the balance further toward constrained self-employment. The literature has demonstrated, in some cases, that the returns to capital for microenterprises in developing countries can be much higher than market interest rates, ${ }^{32}$ suggesting that constrained access to capital may not only restrict entry into self-employment, but may also limit the creation of wage jobs in developing countries. ${ }^{33}$

Another dimension of the business environment that affects the self-employment rate, especially chosen self-employment, is a country's taxation, ${ }^{34}$ business registration and licensing procedures. ${ }^{35}$ When business registration is a costly and/or time consuming procedure, fewer potential choice entrepreneurs may consider registration worthwhile ${ }^{36}$. Likewise, if obtaining permits and business licenses is costly and time consuming, entry into self-employment by choice may be lower. ${ }^{37}$ Of

\footnotetext{
${ }^{28}$ See, for example, the IFS-World Bank Doing Business database (http://doingbusiness.org) or the Global Entrepreneurship Monitor's National Expert Surveys (http://www.gemconsortium.org).

${ }^{29}$ See, for example, http://www.enterprisesurveys.org.

${ }^{30}$ Djankov et. al. (2007) examine constraints to accessing capital in 129 countries.

${ }^{31}$ See Baliamoune-Lutz et. al. (2011).

${ }^{32}$ See de Mel et. al. (2008, 2012a), McKenzie and Woodruff (2006). See Karlan et. al. (2012) for an explanation as to why high returns to capital may not be more frequently observed.

${ }^{33}$ See de Mel et. al. (2010b).

${ }^{34}$ See Djankov et. al. (2010).

${ }^{35}$ See Djankov et. al. (2002). Djankov (2008) provides a more recent survey of the literature linking regulations to entry in developing countries.

${ }^{36}$ See Bruhn (2011) for the case of a reform of business registration procedures in Mexico.

37 See de Mel et. al. (2012b) for an experiment which provided information and lowered the cost of formalization in Sri Lanka.
} 
course, many potential entrepreneurs do not pay taxes and open their business without registration or licenses in developing countries, but when there is a risk of being caught and having to pay a cost $^{38}$ even imperfectly enforced procedures can have a chilling effect on new business creation when they become overly costly to potential entrepreneurs.

A final dimension of the business environment that can have an impact on self-employment and its composition is corruption ${ }^{39}$ and the effectiveness of the legal system. ${ }^{40}$ As self-employed workers are directly responsible (and in cases where damages are concerned, liable) for outcomes resulting from their business activity, potential choice entrepreneurs will likely factor in the risk associated with the various transactions they will need to make before deciding to start or grow a business. ${ }^{41}$ When the contracting environment is reliable and justice is relatively efficient and non-corrupt, this can significantly reduce the expected risk of entering self-employment. Conversely, when an individual fears that the assets or income from his or her enterprise can be arbitrarily seized, this can increase the expected risk of starting a business to the point where the individual chooses not to do so.

\subsection{Labor market regulations}

In addition to overall business environment characteristics, labor market regulations and practices that affect the willingness of employers to create wage jobs will also increase the time that an individual will need to spend to find an available wage job. ${ }^{42}$ For example, minimum wages ${ }^{43}$ and health and safety standards, although providing direct benefits to wage workers who benefit from them, can also impose costs on employers and lead them to create fewer wage jobs. As mentioned above, despite the omnipresence of informality in developing countries, ${ }^{44}$ the simple risk of being caught and having to pay the additional costs can reduce job creation. When fewer wage jobs are created, more workers are pushed into constrained self-employment.

Another type of factor that can indirectly affect self-employment is payroll taxes and, when they exist, employment subsidies. Although payroll taxes are often (at least partially) avoided in many developing countries by a large share of informal firms, a higher payroll tax rate can reduce the incentives to hire wage workers. When this occurs, the number of wage jobs falls and necessity selfemployment increases. To counter this potential negative effect on wage job creation, employment subsidies are a frequently used tool in developing countries. Insofar as these subsidies have an effect on wage employment ${ }^{45}$, they can reduce the share of workers forced into constrained selfemployment.

\footnotetext{
${ }^{38}$ See, for example, Almeida and Carneiro (2011).

${ }^{39}$ See Campos et. el. (2010a, 2010b),

${ }^{40}$ Kaplan et. al. (2007) and Kaplan and Sadka (2011) provide evidence on the effectiveness of the legal system for resolving disputes in Mexico.

${ }^{41}$ See, for example, Brown et. al. (2004).

${ }^{42}$ See Djankov and Ramalho (2009) for an overview.

${ }^{43}$ See Margolis (2014) for a discussion of the implementation of minimum wages in the developing world and Gindling (2014) for an overview of their effects.

${ }^{44}$ For a recent assessment, see Charmes (2012).

${ }^{45}$ Betcherman, Olivas and Dar (2004) survey the impact of employment programs, including wage subsidies, in developing countries and conclude that the impact is limited, at best, yet imply important deadweight losses and substitution costs.
} 


\section{How many self-employed are "entrepreneurs"?}

In order to consider the question of whether self-employment in the developing world corresponds to a developed-world preconception of entrepreneurship ${ }^{46}$, an appropriate definition of entrepreneurship is needed ${ }^{47}$. Typical dictionary definitions of entrepreneur include ${ }^{48}$ "a person who organizes and manages any enterprise, especially a business, usually with considerable initiative and risk" or $^{49}$ "the owner or manager of a business enterprise who, by risk and initiative, attempts to make profits." Both of these definitions emphasize two main dimensions, initiative and risk. The latter definition also stresses the profit objective, whereas the former focuses more on the actions undertaken. It is worth noting that neither of these definitions corresponds cleanly to the choice versus necessity distinction, since in both cases the self-employment enterprise faces risk, and both types of self-employment require initiative to start the enterprise. The definition that focuses on the profit objective, however, can find a counterpart in the choice-based type of self-employment in the developing world. ${ }^{50}$

The most direct source of information on "standard definition" entrepreneurs can be found in the GEM entrepreneurial attitudes questions. Individuals are asked about their motives for pursuing selfemployment opportunities, and nearly half of all respondents in the 2009 survey replied that their main objective was to increase personal income (see Figure 3). This corresponds more to the profitdriven dictionary definition of entrepreneurship, although its links to choice versus necessity selfemployment are less clear, as even necessity-driven self-employed attempt to increase their income, typically starting from zero. Other questions about attitudes are also available, including questions on expected hiring and additional variables that allow for the measurement of necessity-driven TEA and improvement-driven opportunity TEA. These latter variables seem closest to the literature's definition of constrained versus chosen self-employment, but are only available for new enterprises. ${ }^{51}$

\footnotetext{
${ }^{46}$ See Bögenhold, Meinonen and Akola (2013) for a different perspective on this distinction.

${ }^{47}$ The issue of measurement of entrepreneurship relative to self-employment in the developed world has been addressed by Bjuggren, Johansson and Stenkula (2010).

${ }^{48}$ Random House Dictionary (http://dictionary.reference.com/browse/entrepreneur?s=t).

${ }^{49}$ Collins English Dictionary - Complete \& Unabridged 10th Edition (http://dictionary.reference.com/browse/ entrepreneur?s=t).

50 Schoar's (2010) definition of "transformational" entrepreneurship corresponds more closely to this distinction, although one might further disaggregate her categories into truly transformational entrepreneurs (with revolutionary ideas and high growth potential) and more traditional, vocational entrepreneurs.

${ }^{51}$ Xavier et. al. (2013) present somewhat counterintuitive results drawn from these data, such as higher necessity-driven TEA in non-EU Europe, where formal social protection systems exist, than in any other region, including Sub-Saharan Africa, where they are often inadequate or entirely absent. These results may be driven by sampling issues, but suggest that the variables should be used with caution.
} 


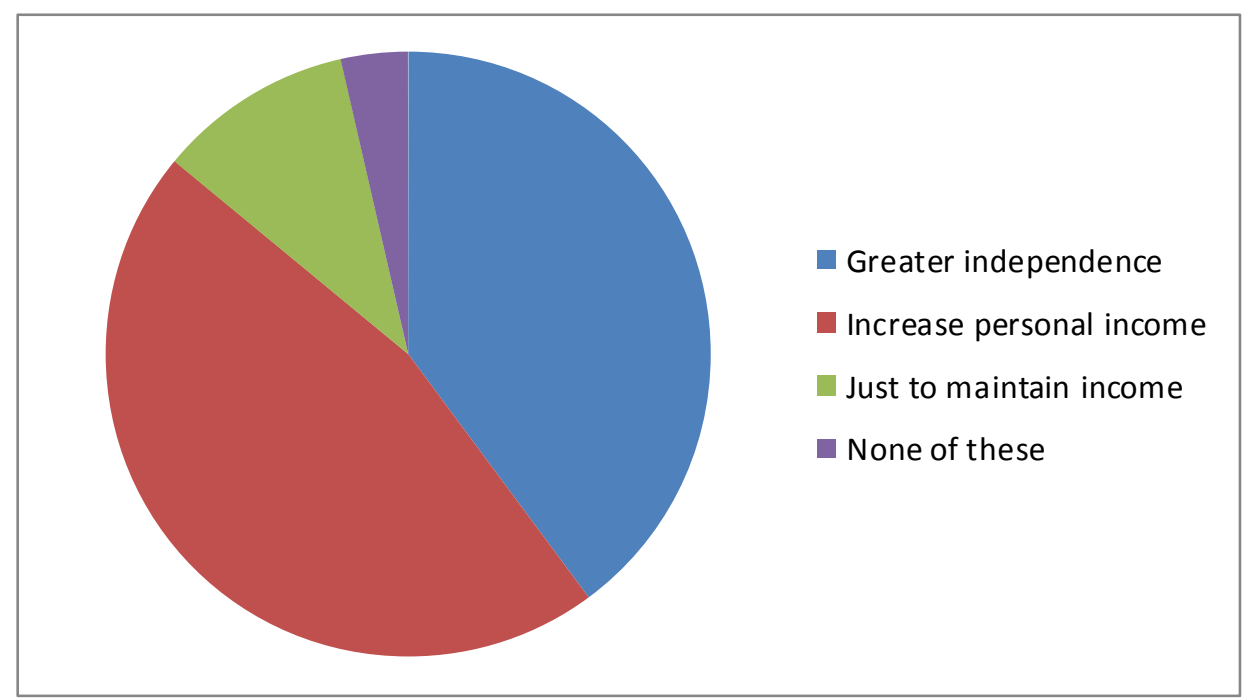

Source: GEM APS 2009 Individual Data, author's calculations.

Gindling and Newhouse (2012) also try to understand the distinction between choice and necessity entrepreneurs, using a breakdown of successful and potentially successful versus unsuccessful self employed. Their definition of success is either a) having employees; or b) living in a household with per capita consumption over the $\$ 2 /$ day poverty line. The latter definition is based on the idea that successful entrepreneurs earn enough to pull their families out of poverty, while the former supposes that a minimum level of success corresponds to earning enough revenue to be able to afford to hire outside labor. In both definitions, one would expect choice entrepreneurs, especially those motivated by profit, to be among the successful (or potentially successful) self-employed. Using the methodology of Grimm, Knorringa and Lay (2012), Gindling and Newhouse (2012) find that, according to both definitions, just over 35 percent of self employed are "high potential", and that there is significant variability across regions (see Table 3 ). Moreover, and as might be suspected, the share of "entrepreneurs" among the self employed is highest in high income countries, and is roughly increasing by income level. 
Table 3: Share of "High Potential" Self-Employed by Region and Income Level

\begin{tabular}{|r|cc|}
\hline & \multicolumn{2}{c|}{ Definition } \\
& Employer & \$2 / Day \\
\hline \hline All Low and Middle Income Countries (50,38) & $36 \%$ & $37 \%$ \\
Region (Low and Middle Income) & & \\
East Asia and Pacific (6,6) & $34 \%$ & $43 \%$ \\
Europe and Central Asia (6,2) & $55 \%$ & $63 \%$ \\
Latin America and the Caribbean (15,10) & $40 \%$ & $47 \%$ \\
Middle East and North Africa (4,3) & $41 \%$ & $50 \%$ \\
South Asia (3,2) & $36 \%$ & $29 \%$ \\
Sub-Saharan Africa (16,15) & $27 \%$ & $52 \%$ \\
Per Capita GNI & & \\
Low Income (15,12) & $34 \%$ & $42 \%$ \\
Lower Middle Income (21,17) & $34 \%$ & $35 \%$ \\
Upper Middle Income (14,9) & $42 \%$ & $47 \%$ \\
High Income (23,0) & $72 \%$ & - \\
\hline
\end{tabular}

Source: Gindling and Newhouse (2012), tables 10 and 11

Notes: Numbers in parentheses reflect the number of countries in the category for which the estimates were calculated. "Employer" definition uses the presence of employees as the measure of success, while "\$2/day" definition uses per capita consumption of the household of at least $\$ 2 /$ day as the measure of success.

Perhaps the most direct assessment of the importance of "entrepreneurs" among the self employed, albeit limited to West Africa, comes from the original paper by Grimm, Knorringa and Lay (2012). Using a set of "1-2-3" surveys, their objective is to identify three groups: the top performers (defined as the top $40 \%$ of self-employed, based on value added per unit of physical capital, among the $25 \%$ largest enterprises defined the amount of capital), the "constrained gazelles" (entrepreneurs who resemble the top performers but are not yet successful) and "survival entrepreneurs with fundamentally different characteristics". They propose an econometric methodology based on the rich set of characteristics of the self-employed and their enterprises available in their data, which allows them to identify those self-employed among those not classified as "top performers" whose characteristics are the most similar. As seen in Table 4 below, they arrive at figures that are quite similar to Gindling and Newhouse (2012); roughly one third of self-employed are true "entrepreneurs" and two thirds constrained in their surveyed countries.

Table 4: Share of Each Type of Self Employed Worker in the Informal Sector

\begin{tabular}{|c|c|c|c|c|c|c|c|}
\hline & Benin & Burkina Faso & Côte d'Ivoire & Mali & Niger & Senegal & Togo \\
\hline Top-performers & $10 \%$ & $10 \%$ & $10 \%$ & $10 \%$ & $10 \%$ & $10 \%$ & $10 \%$ \\
\hline Constrained gazelles & $24 \%$ & $22 \%$ & $34 \%$ & $27 \%$ & $25 \%$ & $31 \%$ & $19 \%$ \\
\hline Survivalists & $66 \%$ & $68 \%$ & $56 \%$ & $63 \%$ & $65 \%$ & $59 \%$ & $71 \%$ \\
\hline
\end{tabular}

Source: Grimm, Knorringa and Lay (2012), table 8.

Notes: By definition, the share of "top performers" in each country is $10 \%$.

\section{Is there too much self-employment in the developing world?}

The previous sections have established that self-employment comprises the majority of jobs in the developing world, and that only a third of self-employed are what are normally thought of as "entrepreneurs". However, beyond the simple acknowledgement of the fact that many selfemployed do not occupy their current status by choice (and thus welfare could potentially be 
improved by shifting them out of self-employment and into wage employment, if it exists), excessively high self-employment may actually inhibit economic development ${ }^{52}$.

The productivity of firms, and the microenterprises created by the self-employed in particular, is lower in the developing world than in developed countries (see Table 5). When productivity is low, less income is available for redistribution, either to workers (through wages) or to the entrepreneur (as the residual claimant). The lower level of income can be associated with more poverty and fewer resources available for reinvesting in enterprises, thereby stunting growth. In this manner, low productivity can lead to lower welfare in the current situation and a lower chance of a country's being able to grow into higher levels of income through investment and development. ${ }^{53}$

Table 5: Income Level and Productivity

\begin{tabular}{|c|c|c|}
\hline Country & $\begin{array}{c}\text { GDP per } \\
\text { capita, Dollars }\end{array}$ & $\begin{array}{c}\text { Sales per employee, } \\
\text { Dollars }\end{array}$ \\
\hline US & 42736 & 433884 \\
\hline UK & 37886 & 457674 \\
\hline Japan & 35699 & 428336 \\
\hline France & 35100 & 393024 \\
\hline Germany & 33838 & 379341 \\
\hline Greece & 22410 & 320859 \\
\hline Poland & 7967 & 178525 \\
\hline Brazil & 4787 & 144831 \\
\hline Colombia & 3170 & 150198 \\
\hline Ecuador & 2814 & 71263 \\
\hline Morocco & 1952 & 105271 \\
\hline China & 1761 & 66885 \\
\hline Indonesia & 1249 & 80203 \\
\hline Philippines & 1090 & 102975 \\
\hline India & 741 & 120656 \\
\hline
\end{tabular}

Source: Bloom et. al. (2010), table 1.

As noted in section 2, many factors can limit the creation of wage jobs and drive people into selfemployment, but even chosen self-employment can be of low productivity. Bloom et. al. (2010) mention several causes for low productivity in developing country enterprises, including poor infrastructure, informality, overly-restrictive regulations and trade policies, low human capital, poor management practices and limited access to finance. In fact, de Mel, McKenzie and Woodruff (2008) show that access to finance constraints in particular can be so binding that projects with rates of return far above market rates can go unfinanced and growth opportunities are wasted. In a follow-up paper (de Mel, McKenzie and Woodruff (2012)), they show that providing credit to microentrepreneurs, especially male-owned subsistence firms, can have positive and long-lasting effects on profits and firm survival.

These results suggest that reforms to ease the constraints that limit productivity can have effects along several dimensions. First, they can improve the productivity and income of those currently self-

\footnotetext{
${ }^{52}$ See Gries and Naudé (2010) for a model along these lines.

${ }^{53}$ This mechanism is a common feature of endogenous growth models; see the October 1990 issue of the Journal of Political Economy for a series of papers all adopting a similar framework.
} 
employed. Second, they can allow the choice entrepreneurs to grow and wage employers in general to create more wage jobs. This allows subsistence entrepreneurs to move into (more productive) wage jobs. As a result of the higher productivity and fewer wasted resources, the country can grow and develop, and the share of wage employment can gradually increase.

Figure 4 shows that this is actually the typical profile traced by countries at various stages of development. ${ }^{54}$ Non-agricultural, low productivity self-employment initially replaces agricultural employment as the least developed countries start to grow. However, at a level of GDP per capita of roughly 6002005 PPP US Dollars, workers begin to shift out of low productivity self employment and into wage work. However, the real structural changes appear to occur as countries cross the threshold from lower-middle to upper-middle income status (\$1006 in 2010 US Dollars). At this point, successful self employment starts to grow and agricultural employment starts shifting into nonagricultural wage employment, while low-productivity self-employment and unpaid labor continues to fall. Thus although developing countries may have a majority of their jobs outside of the wage sector, economic growth appears to come with a steady reduction in self employment and an increase in wage employment.

Figure 4: Evolution of Employment Status with Per Capita GDP

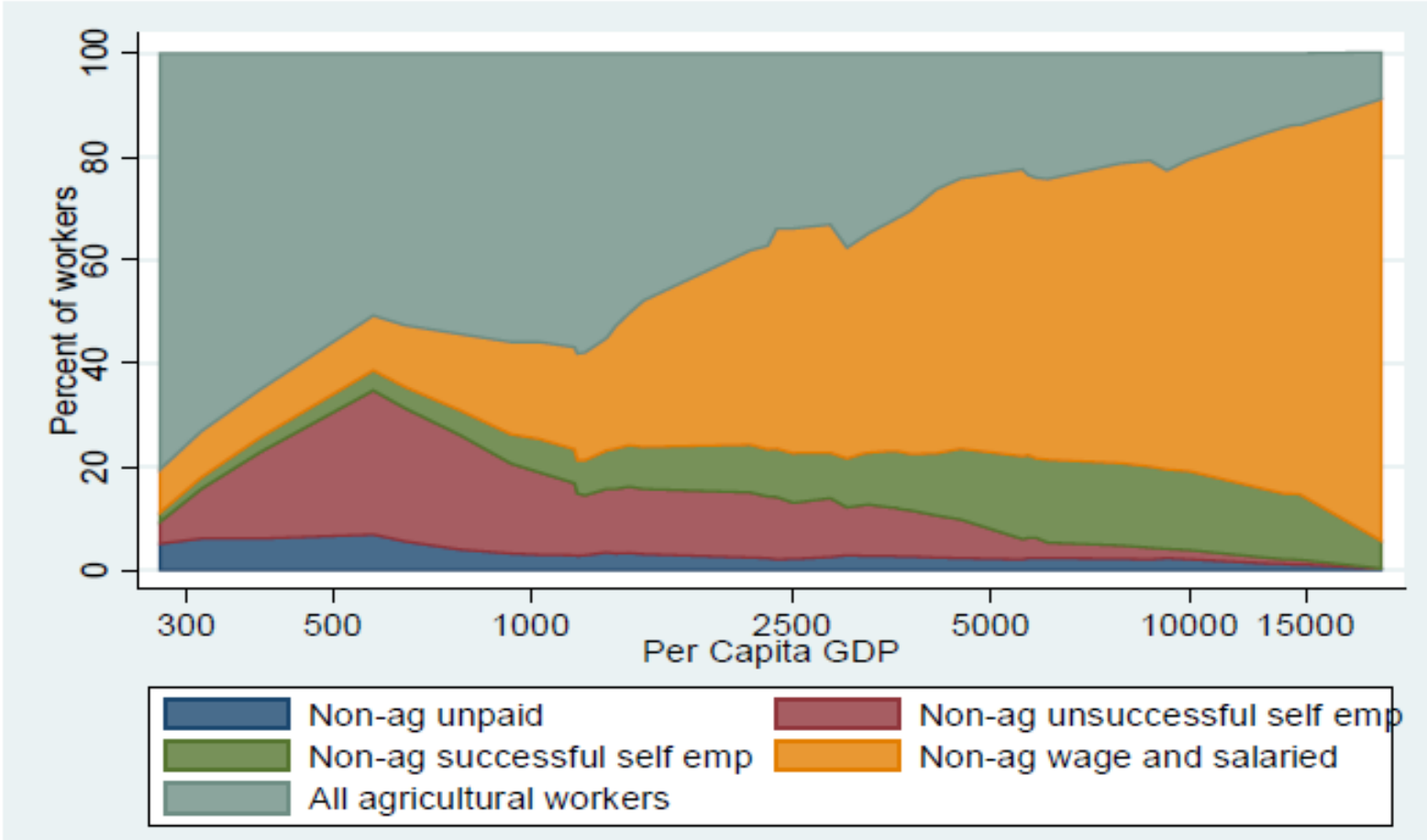

Source: Gindling and Newhouse (2012) Figure 1 Panel A.

Notes: Successful is defined as living in a household with per capita consumption superior to $\$ 2 /$ day.

\section{Conclusion}

This paper has examined self employment and entrepreneurship in the developing world from four angles. First, it discussed how to quantify the amount of self-employment using available data

\footnotetext{
${ }^{54}$ Development processes such as those described in Figure 4 have been modeled extensively in the macroeconomic dynamics literature. See, for example, Alvarez-Cuadrado and Poschke (2011), Gollin et. al. (2002, 2004) and McMillan and Rodrik (2011).
} 
sources. Second, it addressed the issue of chosen versus constrained self-employment. Third, it considered the extent to which self-employment in the developing world can be considered "true" (transformational or vocational, as opposed to necessity) entrepreneurship. Lastly, it discussed the links between self employment, productivity and economic growth.

In response to the first question, best estimates appear to suggest that over half of jobs in the developing world are in self employment, although the measure can differ broadly based on several factors. First, family farms and household enterprises, insofar as they involve unpaid contributing family workers, need to be counted among the self employed. Second, individual-based data sources should be favored over firm-side data sources and expert surveys. Third, depending on the level of detail required, different individual-based data sets can be used, but proxy response and nonrepresentativity can be important issues. Lastly, it is important to ensure common definitions are used when comparing self-employment rates across countries, and one should be wary of using imputed data, especially for measuring subjects like self-employment in data-poor regions such as Sub-Saharan Africa.

Concerning the choice versus constraints issue, several factors were highlighted that determine overall self-employment rates and the share of self-employment that is chosen. Social protection systems were identified as allowing individuals to avoid subsistence self-employment, while labor market frictions were a source of higher self-employment rates. The business environment, in particular business registration and licensing, access to finance and corruption and judicial systems, were noted as key determinants of the share of chosen self-employment and the overall level of wage employment. Labor market regulations and payroll taxes/wage subsidies were also identified as potential factors that could determine the availability of wage employment and the share of subsistence self-employed.

The discussion of the share of "true" entrepreneurship focused on definitions and measurement issues, and concluded that roughly one third of self-employed in the developing world are entrepreneurs in the standard sense. Standard definitions of entrepreneurship refer to initiative and risk, as well as profit-seeking behavior, as characteristics of the entrepreneur. Different data sources allow for different measures that approach this definition, with the cleanest measures being those that rely on individual and enterprise characteristics associated with high performance.

Finally, the paper concluded by remarking that governments should not be content with the high level of self-employment in the developing world, although it does serve the purpose of providing subsistence income, since the current situation represents an inefficient utilization of resources. Selfemployment in the developing world tends to be relatively unproductive, and higher levels of productivity can lead to faster growth and higher levels of income. In fact, as countries develop and their institutions evolve, self-employment rates appear to fall naturally and wage employment takes over as the main source of jobs. 


\section{$\underline{\text { References }}$}

Almeida, Rita K. and Pedro Carneiro (2011). "Enforcement of Labor Regulation and Informality" IZA Discussion Papers, no. 5902.

Alvarez-Cuadrado, Francisco and Markus Poschke (2011). "Structural Change Out of Agriculture: Labor Push versus Labor Pull" American Economic Journal: Macroeconomics, vol. 3, no. 3, pp. 127-58.

Baliamoune-Lutz, Mina, Zuzana Brixiova and Leonce Ndikumana (2011). "Credit Constraints and Productive Entrepreneurship in Africa" IZA Discussion Papers, no. 6193.

Bergmann, Heiko, Susan Mueller and Thomas Schrettle (2013). "The Use of Global Entrepreneurship Monitor Data in Academic Research: A Critical Inventory and Future Potentials," International Journal of Entrepreneurial Venturing.

Betcherman, Gordon, Karina Olivas and Amit Dar (2004). "Impacts of active labor market programs : new evidence from evaluations with particular attention to developing and transition countries" World Bank Social Protection Discussion Paper, no. 29142.

Bjuggren, Carl Magnus, Dan Johansson and Mikael Stenkulal (2010). "Using Self-employment as Proxy for Entrepreneurship: Some Empirical Caveats," Research Institute of Industrial Economics Working Paper, no. 845.

Bloom, Nicholas, Aprajit Mahajan, David McKenzie and John Roberts (2010). Why Do Firms in Developing Countries Have Low Productivity? American Economic Review, 100, pp. 619-23.

Bögenhold, Dieter, Jarna Heinonen and Elisa Akolaa (2013). "Entrepreneurship and Independent Professionals: Why do Professionals not meet with Stereotypes of Entrepreneurship?" MPRA Working Paper, no. 51529.

Bosch, Mariano \& Maloney, William F. (2010) "Comparative analysis of labor market dynamics using Markov processes: An application to informality" Labour Economics, 17, pp. 621-631.

Brown, J. David; John S. Earle and Dana Lup (2004). "What Makes Small Firms Grow? Finance, Human Capital, Technical Assistance, and the Business Environment in Romania" IZA Discussion Papers, no. 1343.

Bruhn, Miriam (2011). "License to Sell: The Effect of Business Registration Reform on Entrepreneurial Activity in Mexico," The Review of Economics and Statistics, vol. 93, no. 1, pp. 382-386.

Charmes, Jacques (2012). "The Informal Economy Worldwide: Trends and Characteristics" Margin: The Journal of Applied Economic Research, vol. 6, no. 2, pp. 103-132.

Campos, Nauro F, Ralitza Dimova and Ahmad Saleh (2010a). "Whither Corruption? A Quantitative Survey of the Literature on Corruption and Growth" IZA Discussion Papers, no. 5334.

Campos, Nauro F., Saul Estrin and Eugenio Proto (2010b). "Corruption as a Barrier to Entry: Theory and Evidence" IZA Discussion Papers, no. 5243. 
Cho, Yoonyoung David N. Margolis and David A. Robalino (2012). "Labor markets in low and middle income countries: trends and implications for social protection and labor policies," World Bank Social Protection Discussion Papers, no. 67613.

Chuhan-Pole, Punam, Manka Angwafo Mapi Buitano Allen Dennis Vijdan Korman and M. Louise Fox (2011). Africa Pulse: An analysis of issues shaping Africa's economic future, no. 4 (Washington, DC: The World Bank).

de Mel, Suresh, David McKenzie and Christopher Woodruff (2008). "Returns to Capital in Microenterprises: Evidence from a Field Experiment," The Quarterly Journal of Economics, vol. 123, no. 4, pp. 1329-1372.

de Mel, Suresh, David McKenzie and Christopher Woodruff (2010a). "Who are the Microenterprise Owners? Evidence from Sri Lanka on Tokman versus De Soto" in Josh Lerner and Antoinette Schoar (eds.), International Differences in Entrepreneurship, National Bureau of Economic Research, Inc, , pp. 63-87.

de Mel, Suresh, David McKenzie and Christopher Woodruff (2010b). "Wage Subsidies for Microenterprises" American Economic Review, vol. 100, no. 2, pp. 614-18.

de Mel, Suresh, David McKenzie and Christopher Woodruff (2012a). "One-Time Transfers of Cash or Capital Have Long-Lasting Effects on Microenterprises in Sri Lanka," Science, 335, pp. 962-966.

de Mel, Suresh, David McKenzie and Christopher Woodruff (2012). "The Demand for, and Consequences of, Formalization among Informal Firms in Sri Lanka" IZA Discussion Papers, no. 6442.

De Soto, Hernando (1989). The Other Path, (New York, NY: Harper \& Row Publishers).

Desai, Sameeksha (2009). "Measuring Entrepreneurship in Developing Countries," UNU-WIDER Research Paper, no 2009/10.

Dillon, Andrew, Elena Bardasi, Kathleen Beegle and Pieter Serneels (2012). "Explaining variation in child labor statistics," Journal of Development Economics, vol. 98, no. 1, pp. 136-147.

Djankov, Simeon, Rafael La Porta, Florencio Lopez-De-Silanes and Andrei Shleifer (2002). "The Regulation Of Entry" The Quarterly Journal of Economics, vol. 117, no. 1, pp. 1-37.

Djankov, Simeon, Caralee McLiesh and Andrei Shleifer (2007). "Private credit in 129 countries" Journal of Financial Economics, vol. 84, no. 2, pp. 299-329.

Djankov, Simeon (2008). "The Regulation of Entry: A Survey" CEPR Discussion Papers, no. 7080.

Djankov, Simeon and Rita Ramalho (2009). "Employment laws in developing countries" Journal of Comparative Economics, vol. 37, no. 1, pp. 3-13.

Djankov, Simeon, Tim Ganser, Caralee McLiesh, Rita Ramalho and Andrei Shleifer (2010). "The Effect of Corporate Taxes on Investment and Entrepreneurship" American Economic Journal: Macroeconomics, vol. 2, no. 3, pp. 31-64. 
Fields, Gary S. (2012). Working Hard, Working Poor: A Global Journey, (Oxford: Oxford University Press).

Gindling, T.H. (2014). "Minimum Wages and Povert in Developing Countries," IZA World of Labor.

Gindling, T. H. and David Newhouse (2012). "Self-employment in the developing world," World Bank Policy Research Working Paper, no. 6201.

Gollin, Douglas, Stephen Parente and Richard Rogerson (2002). "The Role of Agriculture in Development" American Economic Review, vol. 92, no. 2, pp. 160-164.

Gollin, Douglas, Stephen L. Parente and Richard Rogerson (2004). "Farm Work, Home Work, and International Productivity Differences" Review of Economic Dynamics, vol. 7, no. 4, pp. 827-850.

Gries, Thomas and Wim Naudé (2010). "Entrepreneurship and structural economic transformation" Small Business Economics, vol. 34, no. 1, pp. 13-29.

Grimm, Michael, Peter Knorringa and Jann Lay (2012). "Constrained Gazelles: High Potentials in West Africa's Informal Economy," World Development, vol. 40, no. 7, pp. 1352-1368.

Kaplan, David S. and Joyce Sadka (2011). "The Plaintiff's Role in Enforcing a Court Ruling: Evidence from a Labor Court in Mexico" IDB Publications, no. 38198.

Kaplan, David S., Joyce Sadka and Jorge Luis Silva-Mendez (2007). "Litigation and settlement : new evidence from labor courts in Mexico" World Bank Policy Research Working Paper, no. 4434.

Karlan, Dean, Ryan Knight and Christopher Udry (2012). "Hoping to Win, Expected to Lose: Theory and Lessons on Micro Enterprise Development" NBER Working Papers, no. 18325.

Margolis, David N. (2014). "Positive and Negative Implications of Introducing Minimum Wages in Middle and Low Income Countries,' IZA World of Labor.

Margolis, David N., David Newhouse and Michael Weber (2010a), "Employment changes and the crisis: What happened in data-poor countries?" Presented at 5th IZA/World Bank Conference: Employment and Development, Cape Town, South Africa.

Margolis, David N., David Newhouse and Michael Weber (2010b), "Improving Policy Making through Better Data," The World Bank, mimeo.

Margolis, David N. and David A. Robalino (2013). "Skills, Self-Employment and Entrepreneurial Success," Centre d'Economie de la Sorbonne, mimeo.

McKenzie, David J. and Christopher Woodruff (2006). "Do Entry Costs Provide an Empirical Basis for Poverty Traps? Evidence from Mexican Microenterprises" Economic Development and Cultural Change, vol. 55, , pp. 3-42.

McMillan, Margaret S. and Dani Rodrik (2011). "Globalization, Structural Change and Productivity Growth" NBER Working Papers, no. 17143.

Meyer, Bruce D (1990). "Unemployment Insurance and Unemployment Spells," Econometrica, vol. 58, no. 4, pp. 757-82. 
Perry, Guillermo, William Maloney, Omar Arias, Pablo Fajnzylber, Andrew Mason and Jaime Saavedra-Chanduvi (2007). Informality: Exit and Exclusion (Washington, DC: The World Bank).

Poschke, Markus (2013a). "'Entrepreneurs out of necessity': a snapshot" Applied Economics Letters, vol. 20, no. 7, pp. 658-663.

Poschke, Markus (2013b). "The Decision to Become an Entrepreneur and the Firm Size Distribution: A Unifying Framework for Policy Analysis" IZA Discussion Papers, no. 7757.

Poschke, Markus (2013c). "Who becomes an entrepreneur? Labor market prospects and occupational choice" Journal of Economic Dynamics and Control, vol. 37, no. 3, pp. 693-710.

Sandefur, Justin (2010). "On the Evolution of the Firm Size Distribution in an African Economy," CSAE Working Paper Series, no. 2010-05.

Schoar, Antoinette (2010). "The Divide between Subsistence and Transformational Entrepreneurship," in Lerner, Josh and Scott Stern (eds.) Innovation Policy and the Economy, volume 10, (Cambridge, MA: National Bureau of Economic Research), pp. 57-81.

Tokman, Victor E. (2007). "Modernizing the informal sector" United Nations, Department of Economics and Social Affairs, Working Papers, no. 42.

Tybout, James R. (2000). "Manufacturing Firms in Developing Countries: How Well Do They Do, and Why?" Journal of Economic Literature, vol. 38, no. 1, pp. 11-44.

Weber, Michael and Michaela Denk (2011) "Avoid Filling Swiss Cheese with Whipped Cream: Imputation Techniques and Evaluation Procedures for Cross-Country Time Series," International Monetary Fund Working Paper, no. WP/11/151.

World Bank (2012). World Development Report 2013: Jobs, (Washington, DC: The World Bank).

Xavier, Siri Roland, Donna Kelley, Jacqui Kew, Mike Herrington and Arne Vorderwülbecke (2013) Global Entrepreneurship Monitor 2012 Global Report, http://www.gemconsortium.org/docs/ download/2645. 